\title{
Brine Shrimp Lethality Bioassay: A Tool for Drug Discovery from Natural Products
}

\author{
George Owusu-Dapaah ${ }^{1}$, Nicolas I.Y. Fiagbe ${ }^{2}$ \\ ${ }^{1}$ Department of Pharmaceutical Sciences, Kumasi Polytechnic, P.O.Box 854, Kumasi, Ghana. \\ Email:godapaab61@yaboo.com \\ ${ }^{2}$ Department of Pharmaceutical Chemistry, Kwame Nkrumah University of Science and \\ Technology, Kumasi, Ghana
}

\begin{abstract}
This study demonstrates the importance of the Brine Shrimp Bioassay in drug discovery. It uses two medicinal plants, Zanthoxylum xanthoxyloides and Tiliacora funifera. Extracts of Zanthoxylum xanthoxyloides were prepared using water, ethanol, chloroform and diethylether, and each subjected to Brine Shrimp Bioassay. The bioactivities of the extracts were found to be in the order diethylether ( $\mathrm{LD} 50=0.958 \mathrm{mg} / \mathrm{ml}$ ), followed by ethanol (LD50=1.874 mg/ml), water $(\mathrm{LD} 50=2.322 \mathrm{mg} / \mathrm{ml})$, and chloroform $(3.518 \mathrm{mg} / \mathrm{ml})$. From Tiliacora funifera is isolated the compound funiferine, which is derivatized to obtain o-methylfuniferine and o-isopropylfuniferine. These were subjected to the brine shrimp bioassay, and the structure -activity relationship (SAR) was determined. The results showed that o-isopropylfuniferine is the most bioactive (LD50 $=9.07 \mathrm{mg} / \mathrm{ml}$ ), followed by o-methylfuniferine (LD50 $=38 \mathrm{mg} / \mathrm{ml}$ ) with funiferine showing the least activity $(\mathrm{LD} 50=50.25 \mathrm{mg} / \mathrm{ml})$. The SAR of the compounds indicates that the activity of the compounds increases as the size of the group on the phenolic $\mathrm{OH}$ is increased, (i.e. isopropyl $\left(\mathrm{C}_{3} \mathrm{H}_{7}\right)>$ methyl $\left(\mathrm{CH}_{3}\right)>$ hydrogen $(\mathrm{H})$ ), which suggests that bulkier groups may give more potent compounds. These two results show that the brine shrimp bioassay can be used as a tool in the search for more bioactive compounds from natural products.
\end{abstract}

Keywords: Brine Shrimp Bioassay, Zanthoxylum xanthoxyloides, Funiferine; o-methylfuniferine,o-isopropylfuniferine.

\section{Introduction}

It is no longer considered useful for natural product chemists and researchers to just isolate natural compounds, characterize them, determine their structures and let them sit on laboratory shelves for nothing. There is the need for bioassay methods to screen natural products for biological activity and to guide the isolation of useful compounds.

The Brine Shrimp Lethality Bioassay is one such method which has been used in screening for bioactive natural products. It is a rapid, safe, reliable, inexpensive and convenient method by which natural product extracts, fractions or pure compounds are tested for bioactivity. Brine Shrimp Bioassay has been used in-house as a 'bench top bioassay' for the discovery and purification of bioactive natural products, and it is an excellent choice for preliminary toxicity investigations of natural products (Carballo et al, 2002; Michael et al, 1956).

The Brine Shrimp Bioassay has been used in the determination of the bioactivity of synthetic compounds (Almeida et al, 2002) and a variety of plant products (Silva et al, 2007; Lhullier et al 2006; Krishnaraju et al, 2006; Stefanello et al, 2006; Padmaja et al, 2002). It has also been employed as a prescreening tool in the search for antitumour agents (Couladis et al 2002; Anderson et al, 1991). This bioassay has also been widely used in searching for anticancer agents from glycoalkaloids and other chemical groupings from medicinal plants (Friedman et al, 2005; Lee et al, 2004; Esteves et al 2002). It is, therefore, a tool in modern day drug discovery from medicinal plants and hence its application in this study.

The Brine Shrimp, Artemia salina leach, is of the crustacean family of aquatic animals. The shrimp family normally produces live offspring. However, under unfavorable conditions, such as winter and drought, they may lay eggs which are well protected in cysts. The cysts can lie unhatched for several years, and wait for favourable environments before they 
hatch. The Artemia cysts hatch within 24 hours of incubation and go through five stages of development, instar I, instar II and instar III, etc stages. The instar III stage is reached 24 hours after hatching. The instar I nauplii are not sensitive, but the instar II and III are sensitive and it is these stages that are employed in the bioassay. Thus the Artemia nauplii should be used after 48 hours of incubation if good and reproducible results are to be obtained (McLaughlin et al, 1991).

In this work the usefulness of the Brine Shrimp Lethality Bioassay in modern day drug discovery from plants products, will be demonstrated using products from two medicinal plant Zanthoxylum xanthoxyloides and Tiliacora funifera.

Zanthoxylum xanthoxyloides (family Rutaceae) is a stout tree which grows up to 8 metres high with grey trunk covered with corky thorns on its branches. The bark and wood are light yellow in colour slightly aromatic in odour and minty in taste. The alcoholic preparation of the bark and leaves is found to exhibit broad spectrum antimicrobial properties. This plant also possesses antisickling, antirheumatic, anticancer, antihypertensive and analgesic effects (Egunyomi et al, 2009; Ghana Herbal pharmaco, 1992; Lewis W.K and Elvin-Lewis M.P, 1977).

Tiliacora funifera Olive (family Menispermaceae) has been used in folklore medicine in the treatment of various diseases including gastric fever, strangulated hernia and various menstrual disorders (Kubo, 1983).

\section{Aim and objectives}

In this work, the versatility of the Brine Shrimp Lethality Bioassay in drug discovery from natural products will be demonstrated in two ways.

(i) The test will be used as a guide in the extraction of bioactive constituents of medicinal plants, and will determine which solvent extract will take up the bioactive constituents.

(ii) The bioassay will also be employed in the determination of the structure-activity relationship of an isolated plant constituent and its derivatives, so that direction can be given to the search for more bioactive compounds.

\section{Experimental procedure}

\subsection{Extracts from Zanthoxylumxanthoxyloides}

Extracts of the dry bark of Zanthoxylum xanthoxyloides were prepared using chloroform, ethanol, diethylether and water. The dried bark of the plant was powdered and $5 \mathrm{~g}$ samples were weighed into separate $250 \mathrm{ml}$ flat bottomed flasks. $50 \mathrm{ml}$ of chloroform was added to a sample in one of the flasks and stopped. This was repeated for the other solvents so that a solvent is added to each sample. These flasks were left for 24 hours and then filtered to give extracts of concentration, $100 \mathrm{mg} / \mathrm{ml}$. These extracts were used for the bioassay.

\subsection{Extraction, isolation and characterization of Funiferine}

Funiferine, the main constituent of the plant Tiliacora funifera, was first isolated and characterized by Dabrah (1974). In this study, funiferine is isolated from the powdered root of Tiliacora funifera, and its structure and properties confirmed by comparing with literature values (Fig.1and appendix) (DwumaBadu et al, 1975a; Dwuma-Badu et al, 1975b; Dabrah, 1974). A sample of funiferine was subjected to the Brine Shrimp Lethality bioassay.

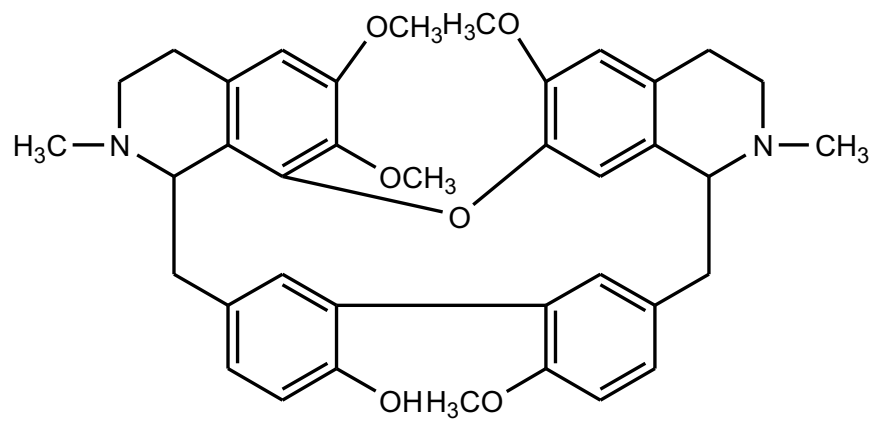

Fig 1: Structure of funiferine

\subsection{Derivatisation of funiferine}

\section{(I) O-Metbylfuniferine}

O-Methylfuniferine was prepared by reacting diazomethane (prepared in situ by reacting sodium nitrite, methylurea and concentrated hydrochloric acid at $0^{\circ} \mathrm{C}$ ) with funiferine. The product was purified by column chromatography using alumina as stationary phase and $10 \%$ ethylacetate in ether as the mobile phase. O-methylfuniferine was confirmed by comparing melting point, $\mathrm{Rf}$ values, U.V 
spectroscopy and I.R. spectroscopy with literature values. The structure of o-methylfuniferine, which was first synthesized and characterized by Dabrah, is shown in Fig. 2 (Dabrah, 1974). U.V. analysis showed no bathochromic shift when sodium hydroxide was added, indicating the absence of any phenolic-OH group. Comparing the I.R spectrum of $\mathrm{O}-$ methylfuniferine with that of funiferine showed new bands at $1220 \mathrm{~cm}^{-1}$ and $1030 \mathrm{~cm}^{-1}$ for o-methylfuniferine, which is an indication of an additional $\mathrm{O}-\mathrm{CH}_{3}$ group on the funiferine structure (Dabrah, 1974). These new bands agree with literature data and thus confirm the product as o-methylfuniferine.

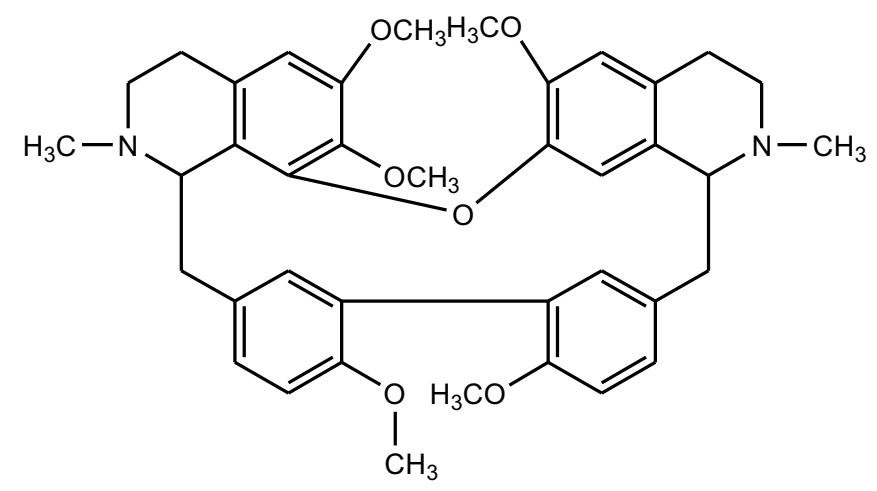

Fig 2: Structure of o-methylfuniferine

\section{(ii) O-Isopropylfuniferine}

O-isopropylfuniferine is synthesized when funiferine is treated with sodium hydride and then isopropyl bromide in dry dimethylsulphoxide (DMSO). The product is purified by column chromatography to obtain yellowish feathery crystals of $o$-isopropylfuniferine.

The product was confirmed as $o$ isopropylfuniferine (Fig. 3) when U.V, I.R, mass spectroscopy and nuclear magnetic resonance (NMR) spectroscopy are used. U.V analyses indicate that there is no bathochromic shift when sodium hydroxide is added to a solution of the product and this suggests the absence of phenolic-OH group.

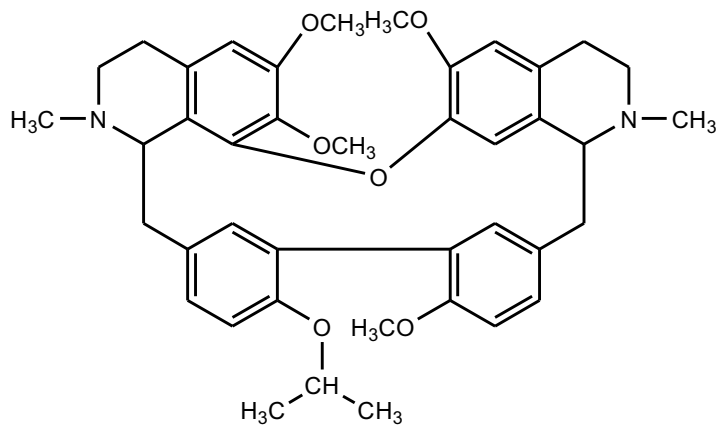

Fig 3: Structure of o-isopropylfuniferine
Comparing the IR spectrum of the product with that of funiferine shows additional bands at $1265 \mathrm{~cm}^{-1}$ and $1055 \mathrm{~cm}^{-1}$ indicating the presence of new other group owing to the presence of the isopropyl group on the phenolic-OH (William, 1989).

A high resolution mass spectrum was ran when using direct insertion probe. The exact mass of the product was obtained as 664, which corresponds to the structure of the compound. Another peak that confirmed the structure was 621 which shows a loss of the isopropyl group (mass of 43). The proton NMR spectrum confirmed the presence of the $o$-isopropyl group (Fig. 4) in place of the phenolic-OH.

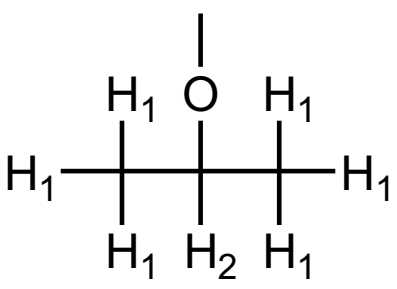

Fig 4: The o-isopropyl group

The isopropyl group has two types of protons, the methyl $\left(\mathrm{CH}_{3}-\right)$ protons, $\mathrm{H}_{1}$, and a methine (-CH-) proton, $\mathrm{H}_{2}$ (Fig. 4). The $\mathrm{CH}_{3}$ - protons will couple with - $\mathrm{CH}$ - proton to give a doublet signal for six protons while the $\mathrm{CH}$ proton couples with the six $\mathrm{CH}_{3}$ protons to give a multiplet. Theoretically these signals will be represented at $\delta 1.3$ for the $\mathrm{CH}_{3}$ protons and $\delta 4.5$ for the $\mathrm{CH}$ proton (William, 1989).

These predictions are well observed on the proton NMR spectrum at $\delta 1.2$ with a doublet signal for six protons and at $\delta 4.4$ with a multiplet signal for one proton. This confirms the compound as omethylfuniferine.

\section{Sample preparation}

\subsection{Zanthoxylum xanthoxyloides extracts}

From each of the extracts of Zanthoxylum xanthoxyloides $1000 \mu \mathrm{l}, 100 \mu \mathrm{l}$ and $10 \mu \mathrm{l}$ aliquots were taken and each placed in a $10 \mathrm{ml}$ vial and left overnight for the solvent to evaporate (except for the aqueous extract which was used directly without evaporation).

\subsection{Funiferine and its derivatives}

Hydrochloride salts of funiferine, omethylfuniferine and o-isopropylfuniferine were prepared and used for the test. The equivalent of $20 \mathrm{mg}$ of each sample was accurately weighed, 
dissolved in chloroform and treated with saturated solution of hydrogen chloride in ether. The solvent was completely removed to obtain the hydrochloride salts.

The equivalent of $20 \mathrm{mg}$ of each sample is dissolved in $2 \mathrm{ml}$ of distilled water. From this stock, $500 \mu \mathrm{l}, 50 \mu \mathrm{l}$ and $5 \mu \mathrm{l}$ aliquots were taken and each placed in a $10 \mathrm{ml}$ vial. These are prepared in triplicates and used for the Brine Shrimp Lethality Bioassay.

\subsection{Hatching the Brine Shrimp Nauplii}

About $50 \mathrm{mg}$ of Artemia cysts are hatched and incubated in a small rectangular plastic dish filled with $50 \mathrm{ml}$ of seawater at room temperature $\left(28^{\circ} \mathrm{C}\right)$. The hatchery is such that there was a plastic divider which is placed such that there is a space under it. The divider divides the dish into two-unequal compartments and the larger compartment has a cover.

The eggs were sprinkled on the seawater in the larger compartment and then covered to provide a dark environment, while the small compartment was left open and illuminated with a fluorescent lamp placed about $20 \mathrm{~cm}$ above the hatchery. Forty-eight hours was allowed for incubation, hatching and development of the nauplii to the instar II and some to the instar III stages. After the 48 hours, the phototropic nauplii which had moved into the smaller compartment (through the perforations in the divider) were collected with a Pasteur pipette and used for the bioassay. The nauplii that were not used after 72 hours are discarded.

\subsection{The brineshrimplethality bioassay}

Each of the vials with a sample was filled with $2 \mathrm{ml}$ of seawater and ten (10) nauplii transferred into each with a Pasteur pipette along with as minimum seawater as possible (to reduce contamination). These vials were then topped up to $5 \mathrm{ml}$ with more seawater and the vials properly covered and incubated under illumination for 24 hours at $28^{\circ} \mathrm{C}$. After the 24 hours the number of live larvae in each vial were counted with the help of a magnifying hand lens to estimate the number of dead nauplii. A nauplius is counted dead if no movement of its appendage is observed within ten (10) seconds (San Franscisco, 1991; D'Agostino, 1965; Reeve, 1963).

\section{Results}

The results of the Brine Shrimp Bioassay have been presented in Tables 1-7. The results show the concentrations and corresponding effect on the brine shrimps i.e. the number of shrimps killed.

Table 1

Results for chloroform extract of zanthoxylum xanthoxyloides.

\begin{tabular}{lccc}
\hline $\begin{array}{c}\text { Concentration } \\
\mathbf{m g} / \mathbf{m l}\end{array}$ & $\begin{array}{c}\text { Initial no. of naupii } \\
\text { (each test) }\end{array}$ & Average survivors & Average dead \\
\hline 1 & 30 & 25 & 5 \\
10 & 30 & 10 & 20 \\
100 & 30 & 0 & 30 \\
Control & 10 & 10 & 0 \\
\hline
\end{tabular}

Table 2

Results for ethanol extract of zanthoxylum xanthoxyloides.

\begin{tabular}{lcrc}
\hline $\begin{array}{c}\text { Concentration } \\
\mathrm{mg} / \mathrm{ml}\end{array}$ & $\begin{array}{c}\text { Initial no. of naupii } \\
\text { (each test) }\end{array}$ & Average survivors & Average dead \\
\hline 1 & 30 & 15 & 15 \\
10 & 30 & 11 & 19 \\
100 & 30 & 0 & 30 \\
Control & 10 & 10 & 0 \\
\hline
\end{tabular}


Table 3

Brine shrimp bioassay results for aqueous extract of zanthoxylum xanthoxyloides.

\begin{tabular}{lcrr}
\hline $\begin{array}{c}\text { Concentration } \\
\mathbf{m g} / \mathbf{m l}\end{array}$ & $\begin{array}{c}\text { Initial no. of naupii } \\
\text { (each test) }\end{array}$ & Average survivors & Average dead \\
\hline 1 & 30 & 21 & 9 \\
10 & 30 & 6 & 24 \\
100 & 30 & 0 & 30 \\
Control & 10 & 10 & 0 \\
\hline
\end{tabular}

Table 4

Brine shrimp bioassay results for diethylether extract of zanthoxylum xanthoxyloides.

\begin{tabular}{lccc}
\hline $\begin{array}{c}\text { Concentration } \\
\text { mg/ml }\end{array}$ & $\begin{array}{c}\text { Initial no. of naupii } \\
\text { (each test) }\end{array}$ & Average survivors & Average dead \\
\hline 1 & 30 & 11 & 19 \\
10 & 30 & 4 & 26 \\
100 & 30 & 0 & 30 \\
Control & 10 & 10 & 0 \\
\hline
\end{tabular}

Table 5

Brine shrimp bioassay results for funiferine.

\begin{tabular}{cccc}
\hline $\begin{array}{c}\text { Concentration } \\
\mathrm{mg} / \mathrm{ml}\end{array}$ & $\begin{array}{c}\text { Initial no. of naupii } \\
\text { (each test) }\end{array}$ & Average survivors & Average dead \\
\hline 10 & 30 & 26.5 & 3.5 \\
50 & 30 & 18.5 & 11.5 \\
100 & 30 & 6 & 24 \\
1000 & 30 & 0 & 30 \\
Control & 10 & 10 & 0 \\
\hline
\end{tabular}

Table 6

Brine shrimp bioassay results for $o$-methylfuniferine.

\begin{tabular}{lccc}
\hline $\begin{array}{c}\text { Concentration } \\
\mathrm{mg} / \mathrm{ml}\end{array}$ & $\begin{array}{c}\text { Initial no. of naupii } \\
\text { (each test) }\end{array}$ & Average survivors & Average dead \\
\hline 10 & 30 & 27.25 & 2.75 \\
50 & 30 & 13 & 17 \\
100 & 30 & 0 & 30 \\
1000 & 30 & 0 & 30 \\
Control & 10 & 10 & 0 \\
\hline
\end{tabular}


Table 7

Brine shrimp bioassay results for $o$-isopropylfuniferine.

\begin{tabular}{lccr}
\hline $\begin{array}{c}\text { Concentration } \\
\mathbf{m g} / \mathrm{ml}\end{array}$ & $\begin{array}{c}\text { Initial no. of naupii } \\
\text { (each test) }\end{array}$ & Average survivors & Average dead \\
\hline 10 & 30 & 26 & 4 \\
50 & 30 & 11 & 19 \\
100 & 30 & 2 & 28 \\
1000 & 30 & 0 & 30 \\
Control & 10 & 10 & 0 \\
\hline
\end{tabular}

The results were analyzed using probit analysis method described by Finney to determine the Ld50 and the 95\% confidence intervals (Finney, 1971). Table 8 and 9 present the analysed results for the bioassay.

Table 8

Probit analysis results of the brine shrimp bioassay for zanthoxylum xanthoxyloides extracts.

\begin{tabular}{lcccc}
\hline Extracts & $\begin{array}{c}\text { LD50-24 hours } \\
\mathbf{M g} / \mathbf{m l}\end{array}$ & $\begin{array}{c}\text { 95\% confidence } \\
\text { interval }\end{array}$ & Chi-square & degree of freedom \\
\hline Chloroform & 3.518 & $3.5167-3.5193$ & 0.00004 & 1 \\
Ethanol & 1.874 & $1.8724-1.8737$ & 0.00001 & 1 \\
Aqueous & 2.322 & $2.3206-2.3234$ & 0.00001 & 1 \\
Diethylether & 0.958 & $0.956-0.960$ & 0.00004 & 1 \\
\hline
\end{tabular}

Table 9

Probit analysis results of the brine shrimp bioassay of funiferine and its derivatives

\begin{tabular}{lcccc}
\hline Extracts & $\begin{array}{c}\mathbf{L D}_{\mathbf{5 0}} \mathbf{- 2 4} \text { hours } \\
\mathbf{\mu g} / \mathbf{m l}\end{array}$ & $\begin{array}{c}\mathbf{9 5 \%} \text { confidence } \\
\text { interval }\end{array}$ & Chi-square & $\begin{array}{c}\text { degree of } \\
\text { freedom }\end{array}$ \\
\hline Funiferine & 50.25 & $34.45-72.83$ & 2.95 & 2 \\
o-methylfuniferine & 38.46 & $21.38-69.88$ & 0.02 & 1 \\
o-isopropylfuniferine & 9.07 & $7.33-11.11$ & 1.43 & 2 \\
\hline
\end{tabular}

\section{Discussion}

Tables 8 and 9 present the probit analysis results of the Brine Shrimp Lethality Bioassays of Zanthoxylum xanthoxyloides extracts and the funiferines respectively. These indicate the lethal doses needed to kill $50 \%$ of the Artemia nauplii $\left(\mathrm{LD}_{50)}\right.$ and the $95 \%$ confidence interval.

\subsection{The Zanthoxylum xanthoxyloides extracts}

From Table 8 it is observed that the various extracts of the plant have different potency and they are in the order Diethylether extract $\left(\mathrm{LD}_{50}=0.958\right.$ $\mathrm{mg} / \mathrm{ml})>$ Ethanol extract $\left(\mathrm{LD}_{50}=1.874 \mathrm{mg} / \mathrm{ml}\right)$ $>$ Aqueous extract $\left(\mathrm{LD}_{50}=2.322 \mathrm{mg} / \mathrm{ml}\right)>$ Chloroform extract $(\mathrm{LD} 50=3.518 \mathrm{mg} / \mathrm{ml})$. The diethylether extract is the most potent of all the extracts. This probably indicates that it extracts more of the constituents of the plant that may be responsible for the pharmacological activities of the plant than the other solvents. Base on this fact, further work can done on this extract to isolate the compounds present in the extract and then test for their activities against the various disease states for which the whole plant has been used.

Again, the low $\mathrm{LD}_{50}$ values of all the extracts $(<10$ $\mathrm{mg} / \mathrm{ml}$ ) also indicate that all the extracts may 
contain some constituents which may be acting against some of the diseases the plant material has been noted for, including antisickling, antimicrobial, antirheumatic, analgesic and antihypertensive (Egunyomi et al, 2009; Ghana Herbal Pharmacop, 1992). These test results can thus be used as a guide for the isolation of active constituents of the plant. If for instance the diethylether extract is found to contain the constituents responsible for, say, the antisickling activity, then diethylether can be used for the extraction and isolation of those constituents and thus leave behind the others which are not needed.

Again, the polarity difference of the solvents can be exploited here. Water and ethanol are very polar solvents which mean that they are likely to extract constituents of the plant which have polar groups on them. On the other hand, chloroform and

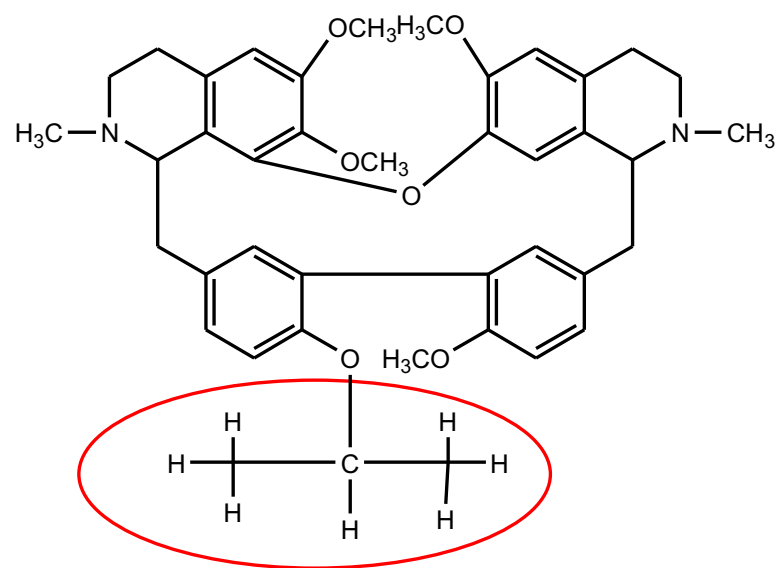

diethylether are non-polar solvents and are likely to extract compounds in the plant which are non-polar.

Thus it can be inferred that the most active constituents in the plant are lipophilic (non-polar) in nature since they are extracted by diethylether, the least polar of all the solvents.

\subsection{Funiferine and its derivatives}

From the results in Table 9, it can be observed that the activity or potency of the funiferines is in the order o-isopropylfuniferine $\left(\mathrm{LD}_{50}=9.07 \boldsymbol{\mu} \mathrm{g} / \mathrm{ml}\right)>$ omethylfuniferine $\left(\mathrm{LD}_{50}=38.46 \mu \mathrm{g} / \mathrm{ml}\right)>$ funiferine $\left(\mathrm{LD}_{50}=50.28 \mu \mathrm{g} / \mathrm{ml}\right)$.

This shows the effect of replacing the $\mathrm{H}$ of the phenolic side group with the alkyl groups, methyl and isopropyl (Fig 5a-c).

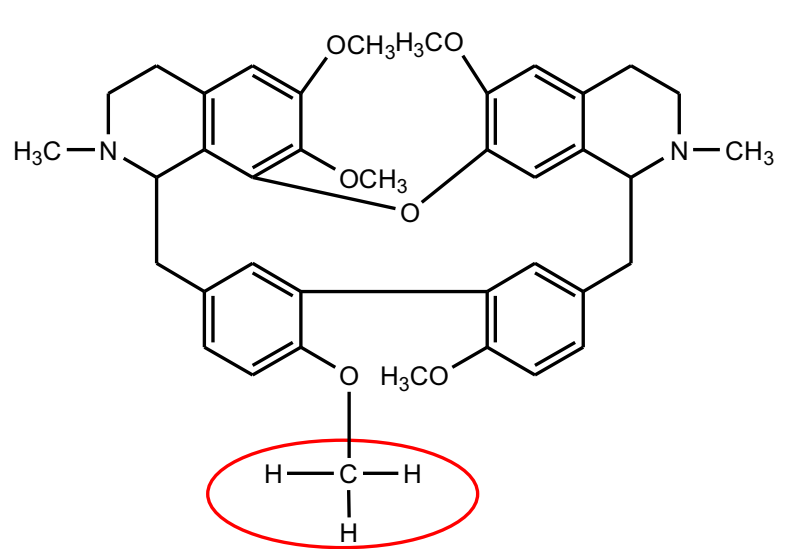

Fig. 5(a): o-isopropylfuniferine $\left(\mathrm{LD}_{50}=9.07\right.$ microgram $\left./ \mathrm{ml}\right)$ Fig. $5(\mathrm{~b})$ : o-methylfuniferine $\left(\mathrm{LD}_{50}=9.07 \mathrm{microgram} / \mathrm{ml}\right)$

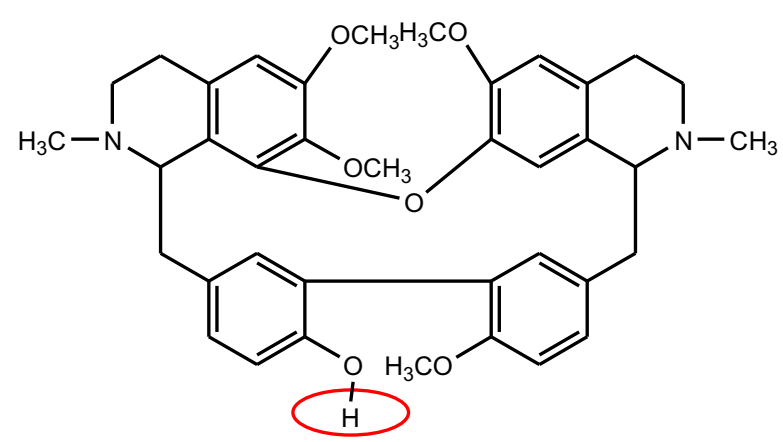

Fig. 5(c): funiferine $\left(\mathrm{LD}_{50}=9.07 \mathrm{microgram} / \mathrm{ml}\right)$

An increase in the size of the group on the oxygen from $\mathrm{H}$ to $\mathrm{CH}_{3}$ to $\mathrm{CH}_{3} \mathrm{CHCH}_{3}$ increases the potency of the compounds and this outlines the structure - activity relationship of this group of compounds. Thus, for us to obtain compounds with better activity, we must aim at putting bulky groups in place of the phenolic $\mathrm{H}$.

The outcome of this work shows that the Brine Shrimp Lethality Bioassay is a useful tool in the determination of structure-activity relationship of related compounds, a feature which is very important in drug discovery. 


\section{Conclusion}

As shown from the result of the Brine Shrimp Test on Zanthoxylum xanthoxyloides extracts, diethylether extracts the most active constituents from Zanthoxylum xanthoxyloides. The order of lethality of the extracts against the brine shrimps is Diethylether extract $\left(\mathrm{LD}_{50}=0.958 \mathrm{mg} / \mathrm{ml}\right)>$ Ethanol extract $\left(\mathrm{LD}_{50}=1.874 \mathrm{mg} / \mathrm{ml}\right)>$ Aqueous extract $\left(\mathrm{LD}_{50}=2.322 \mathrm{mg} / \mathrm{ml}\right)>$ Chloroform extract $(\mathrm{LD} 50=$ $3.518 \mathrm{mg} / \mathrm{ml}$ ).

The Brine Shrimp Bioassay of funiferine and its derivatives have shown that $o$-isopropylfuniferine $\left(\mathrm{LD}_{50}=9.07 \mu \mathrm{g} / \mathrm{ml}\right)>0$-methylfuniferine $\left(\mathrm{LD}_{50}=38.46 \mu \mathrm{g} / \mathrm{ml}\right)>$ funiferine $\left(\mathrm{LD}_{50}=50.28\right.$ $\mu \mathrm{g} / \mathrm{ml})$.

The structure - activity relationship of these compounds suggests that the activity of the compounds increases as the size of the alkyl group put on the phenolic-OH increases.

These results bring to the fore the versatility of the Brine Shrimp Lethality Bioassay in the search for pharmacologically active compounds from natural products. The results can be used to determine appropriate solvents for the extraction of bioactive constituents in medicinal plants; hence time and cost of research are saved. The determination of the structure-activity relationship is also of immense benefit as it gives direction to the search for more effective bioactive compounds. The Brine Shrimp Bioassay is, therefore, an important tool that can be employed in drug discovery from natural products.

\section{Acknowledgement}

The authors are grateful to the government of Ghana for funding this work.

\section{References}

Almeida P.A., Silva T.M.S. and Echevarria A., (2002). Mesoionic 5-Alkyl-1,3-Dithiolium-4-Thiolates: Synthesis and Brine Shrimp Toxicity, Heterocycl Comm, Vol.8, pp. 593-600.

Anderson, J.E., Goetz, C.M., McLaughlin, J.L. and Suffness, M., (1991).A Blind Comparison of Simple Bench-Top Bioassay and Human Tumour Cell Cytotoxicities as Antitumorprescreens, Phytochem Analysis, Vol. 2, pp. 107-111.
Carballo, J. L., Hernández-Inda1 Z. L, Pérez, P. and García-Grávalos, M.D., (2002). BMC, Biotechnology, Vol. 2,pp. 17.

Couladis, M., Badisa, R.B., Baziou, P., Chaudhuri, S.K., Verykokidou, E. and Harvala, C., (2002).Antioxidant and Cytotoxic Activities of Hypericum sp. on Brine Shrimp and Human Cancer Cell Lines, Phytotherapy Research, Vol. 16, No. 8, pp. 719-722.

Dabrah, T.T. , (1974). M.Sc. Thesis, University of Science and Technology, Kumasi, Ghana.

D'Agostino, A.S., (1965). Comparative Studies of Artemia Salina (Development and Physiology): Thesis. New York University 83 P. University microfilms 66-5633, University Microfilms Inc. Ann Arbor Michigan.

Dwuma-Badu, D., Ayim, J.S.K., Tackie, A.N., Knapp, J.E., Slatkin, D.J. and Schiff, P.L., (1975a).Phytochemistry, Vol. 14, pp. 2524-2525.

Dwuma-Badu, D., Ayim, J.S.K., Tackie, A.N., Knapp, J.E., Slatkin, D.J. and Schiff, P.L., (1975b).Experimentia, Vol.31, pp. 1251-1252.

Egunyomi1, A., Moody, J. O. and Eletu, O. M., (2009). Antisickling Activities of Two Ethnomedicinal Plantrecipes Used for the Management of Sickle Cell Anaemia in Ibadan,

Nigeria, African Journal of Biotechnology, Vol. 8, No.1, pp. 020-025.

Esteves-Souza, A., Silva, T.M.S., Alves, C.C.F., de Carvalho, M.G.,Braz-Filho, R. and Echevarria, A., (2002).Cytotoxic Activities Against Ehrlich Carcinoma and Human K562 Leukemia of Alkaloids and Flavonoid from Two Solanum Species, Journal of the Brazilian Chemical Society, Vol.13, pp. 838-842.

Finney, D.T., (1971). Probit Analysis, $\left(^{\text {rd }}\right.$ edn.).Cambridge University Press, Cambridge, pp.20- 49 . 
Friedman, M., Lee, K.R., Kim, H.J., Lee, I.S. and Kozukue, N., (2005). Anticarcinogenic Effects of Glycoalkaloids from Potatoes against Human Cervical, Liver, Lymphoma, and Stomach Cancer Cells, Journal of Agric and Food Chemistry, Vol. 53, pp. 6162-6169.

Hentschel, E., (1968). Die Postembrayonaiem Entwicklungstadien Von Artemia salina Leach Bei Verscheidenen. Temperaturen (Anostracia Crustaceae), Zool Anz, Issue180, pp. 372-384.

Ghana Herbal Pharmacopoeia:Accra Advent Press 1992, pp. 50-58.

Krishnaraju, A. V., Rao, T. V. N., Sundararaju, D., Vanisree, M., Tsay, H-S. and Subbaraju, G. V., (2006). Biological Screening of Medicinal Plants Collected from Eastern Ghats of India Using Artemia salinam (Brine Shrimp Test), International Journal of Applied Science and Engineering, Vol. 4, No. 2, pp.115-125.

Kubo, I. , (1983). Chemicalletters, Vol.7, pp. 979-980.

Lee, K.R., Kozukue, N., Han, J.S., Park, J.H., Chang, E.Y., Baek, E.J., Chang, J.S. and Friedman,M., ( 2004). Glycoalkaloids and Metabolites Inhibit the Growth of Human Colon (HT29) and Liver (HepG2) Cancer Cells, Journal of Agric and Food Chemistry, Vol. 52, pp. 2832-2839.

Lhullier, C., Horta ,P.A. and Falkenberg, M., (2006). Avaliação de Extratos de Macroalgas Bênticas do Litoral Catarinense Utilizando o Teste de Letalidade Para Artemia salina, Revista Brasileira de Farmacognosia, Vol.16, pp. 158-163.
McLaughlin, J.L., Chang, C.J. and Smith, D.L., (1991). "Bench-top"Bioassays for the Discovery of Bioactivenatural Products: An Update. In: Rahman A, ed., Studies in Natural Product Chemistry, Vol. 9, pp. 383-409.

Michael, A.S., Thompson, C.G., and Abramovitz, M., (1956). Artemia salina as a Test Organism for a Bioassay, Science, Vol.123, pp. 464.

Padmaja, R., Arun, P.C., Prashanth, D., Deepak, M., Amit, A. and Anjana, M., (2002).Brine Shrimp Lethality Bioassay of Selected Indian Medicinal Plants, Fitoterapia, Vol.73, No.6, pp. 508-510.

Reeve, M.R., (1963). The Filter Feeding of Artemia II in Suspension of Various Particles, Journal of Experimental Biology, Vol. 40, pp. 207-214.

San Francisco Bay Brand Inc. (1991). The Brine Shrimps Manual. Newark, California, USA.

Silva, T. M. S., Nascimento, R. J. B., Batista, M. M., Agra, M. F. and Camara, C. A., (2007). Brine Shrimp Bioassay of Some Species of Solanum from Northestern Brazil, Brazilian Journal of Pharmacognosy, Vol. 17, No. 1, pp. 35-38.

Stefanello, M.E.A., Salvador, M.J., Ito, I.Y. and Macari, P.A.T., (2006). Avaliação da Atividade Antimicrobiana e Citotóxica de Extratos de Gochnatia polymorpha ssp. fl occosa, Revista Brasileira de Farmacognosia, Vol.16, pp. 525-530.

William, D.H. and Fleming, I., (1989). Spectroscopic Methods in Organic Chemistry, (4 $4^{\text {th }}$ edn.), McGrawHill Book Company, pp. 29-149. 